\title{
Use of dietary feather meal to induce histidine deficiency or imbalance in dairy cows and effects on milk composition
}

\author{
P. Stahel, ${ }^{1}$ N. G. Purdie ${ }^{2}$ and J. P. Cant \\ Department of Animal and Poultry Science, University of Guelph, Ontario, N1G 2W1 Canada
}

\begin{abstract}
Removing His from a postruminal AA infusion decreases milk protein and increases milk fat content. Feather meal is an inexpensive protein source, high in rumen undegradable protein but low in His. The objective of our study was to investigate dietary feather meal as a method for creating a His deficiency or imbalance to alter milk composition. Four dietary treatments were fed for 4 wk each to 8 multiparous mid-lactation Holstein cows in a replicated $4 \times 4$ Latin square design. A standard-protein control diet (SP-C) was formulated to provide $3,100 \mathrm{~g} / \mathrm{d}$ of metabolizable protein (MP). Feather meal was added to the control diet either to replace the MP isonitrogenously (SP-FM) or to increase the MP supply to 3,484 g/d (HP-FM). As an isonitrogenous control for HP-FM, a high-protein diet (HP-C) was formulated with His-adequate protein sources to provide the same MP content as HP-FM. Dry matter intake tended to decrease when feather meal was fed. Predicted flows of digestible His, Met, and Lys, and plasma concentrations of these AA were reduced on both feather meal diets. Predicted flows of total digestible essential AA were not different between HP-FM and SP-C. We concluded that the DMI depression on HP-FM prevented an imbalance of excess AA over His, and created a deficiency of His, Met, and Lys compared with SP-C. Milk production decreased on the 2 feather meal treatments, partly explained by a tendency for DMI to decrease. Milk yield was lowest on SP-FM at $30.3 \mathrm{~kg} / \mathrm{d}$ and highest on HP-C at $37.9 \mathrm{~kg} / \mathrm{d}$. Milk fat yield was not affected by diet but protein and lactose yields were both lower with feather meal. Protein yields were 860 and $998 \mathrm{~g} / \mathrm{d}$, whereas lactose yields were 1,384 and $1,561 \mathrm{~g} / \mathrm{d}$ for SP-FM and HP-FM, respectively. This resulted in a higher fat content and lower protein percentage on FM diets. The ratio of solids-not-fat:fat in milk was lowest on SP-FM at 2.11 compared with
\end{abstract}

Received July 19, 2013

Accepted September 25, 2013.

${ }^{1}$ Corresponding author: pstahel@uoguelph.ca

${ }^{2}$ Current address: Department of Animal Science, University of Vermont, Burlington, VT.
2.56 on SP-C. Adding feather meal to the diet by replacing MP isonitrogenously was more effective at lowering the solids-not-fat:fat ratio than increasing the MP content with an imbalanced protein source.

Key words: feather meal, dairy cow, histidine, milk composition

\section{INTRODUCTION}

Several AA infusion studies in lactating cows have shown that essential AA imbalances or deficiencies can increase the fat content of milk. Histidine imbalance and deficiency are particularly noted for increasing milk fat yields, whereas milk protein yields decrease or remain unaffected (Fraser et al., 1991; Kim et al., 1999; Cant et al., 2001; Weekes et al., 2006). When a His deficiency was created by removing His from an abomasal infusion of $1.1 \mathrm{~kg}$ of AA/d, milk fat yield increased by $181 \mathrm{~g} / \mathrm{d}$ and milk protein yield decreased by $186 \mathrm{~g} / \mathrm{d}$ (Weekes et al., 2006). When a His imbalance was created by infusing $1.1 \mathrm{~kg} / \mathrm{d}$ of all AA except His, milk fat yield increased by $320 \mathrm{~g} / \mathrm{d}$ (Weekes et al., 2006).

Feather meal is an ingredient low in His $(1.15 \%$ of $\mathrm{CP})$ but high in $\mathrm{CP}$ ( $92 \%$ of $\mathrm{DM}$ ) that has poor rumen degradability (35\% of CP), with an RUP digestibility of $65 \%$ (NRC, 2001). The stimulation of milk protein yield by abomasal His in cows consuming feather meal (Kim et al., 1999, 2000) indicates that feather meal is deficient in His. The objective of the present study was to evaluate whether creating a His imbalance or deficiency using feed ingredients would have similar effects on milk composition to His subtraction from a postruminal AA infusion. Test diets were formulated with a high inclusion of feather meal at $12.6 \%$ of DM, or 3.3 $\mathrm{kg} / \mathrm{d}$ of intake. Replacement of MP with His-deficient feather meal was intended to create a His deficiency, whereas increasing MP with feather meal was intended to create a His imbalance.

\section{MATERIALS AND METHODS}

All animal procedures were approved by the Animal Care Committee at the University of Guelph (Guelph, ON, Canada). Eight lactating Holstein cows in their sec- 
Table 1. Ingredient and chemical composition of experimental diets

\begin{tabular}{|c|c|c|c|c|}
\hline \multirow[b]{2}{*}{ Item } & \multicolumn{4}{|c|}{ Treatment $^{1}$} \\
\hline & SP-C & SP-FM & HP-FM & HP-C \\
\hline \multicolumn{5}{|l|}{ Ingredient composition (\% of DM) } \\
\hline Corn silage & 15.2 & 20.4 & 15.1 & 15.1 \\
\hline Alfalfa silage & 21.5 & 21.5 & 21.4 & 21.4 \\
\hline Alfalfa hay & 10.8 & 10.9 & 10.8 & 10.8 \\
\hline Corn, high moisture & 25.8 & 25.9 & 25.8 & 25.8 \\
\hline Megalac $^{2}$ & 1.6 & 1.6 & 1.6 & 1.6 \\
\hline Soybeans, roasted & 5.2 & 0 & 1.5 & 0 \\
\hline Soybean meal & 9.9 & 0 & 3.3 & 5.5 \\
\hline Corn gluten meal & 1.4 & 0 & 0.7 & 6.7 \\
\hline Fish meal & 1.5 & 0 & 0 & 0.7 \\
\hline Canola meal & 0 & 0 & 0 & 2.6 \\
\hline Blood meal & 0 & 0 & 0 & 3.0 \\
\hline Feather meal & 0 & 12.6 & 12.6 & 0 \\
\hline Molasses & 2.9 & 2.9 & 2.9 & 2.9 \\
\hline Vitamin/mineral premix ${ }^{3}$ & 4.1 & 4.1 & 4.1 & 4.1 \\
\hline Rumen-protected $\mathrm{Met}^{4}$ & 0.19 & 0.23 & 0.24 & 0 \\
\hline \multicolumn{5}{|l|}{ Chemical composition } \\
\hline $\mathrm{DM}(\%$, as fed $)$ & 47.4 & 47.6 & 48.8 & 46.9 \\
\hline $\mathrm{CP}(\%$ of $\mathrm{DM})$ & 19.2 & 16.4 & 16.1 & 15.5 \\
\hline Buffer solubility ( $\%$ of $\mathrm{CP}$ ) & 24.5 & 24.1 & 34.7 & 23.7 \\
\hline NDF insolubility ( $\%$ of CP) & 42.5 & 37.0 & 38.8 & 35.3 \\
\hline ADF insolubility ( $\%$ of $\mathrm{CP}$ ) & 11.3 & 7.4 & 14.1 & 11.1 \\
\hline $\mathrm{NDF}(\%$ of DM) & 30.3 & 33.8 & 30.9 & 36.9 \\
\hline $\mathrm{ADF}(\%$ of $\mathrm{DM})$ & 20.4 & 22.8 & 23.4 & 25.2 \\
\hline Cellulose (\% of DM) & 16.3 & 19.0 & 19.0 & 21.0 \\
\hline Lignin $(\%$ of DM) & 4.1 & 3.8 & 4.4 & 4.1 \\
\hline $\mathrm{NFC}(\%$ of DM) & 45.8 & 43.3 & 47.2 & 41.7 \\
\hline Starch (\% of NFC) & 51.0 & 51.8 & 50.6 & 48.6 \\
\hline Fat $(\%$ of $\mathrm{DM})$ & 4.1 & 3.8 & 4.4 & 4.1 \\
\hline Ash (\% of DM) & 8.7 & 8.7 & 8.0 & 8.1 \\
\hline Calculated $\mathrm{NE}_{\mathrm{Lp}}{ }^{5}$ (Mcal/kg of DM) & 1.56 & 1.52 & 1.51 & 1.48 \\
\hline Calculated MP ( $\%$ of DM) & 12.6 & 12.8 & 14.1 & 14.0 \\
\hline \multicolumn{5}{|c|}{$\begin{array}{l}{ }^{1} \mathrm{SP}-\mathrm{C}=\text { standard-protein control diet; } \mathrm{SP}-\mathrm{FM}=\text { feather meal was added to the control diet to replace the } \mathrm{M} \\
\text { isonitrogenously; HP-FM = feather meal was added to the control diet to increase the MP supply to } 3,484 \mathrm{~g} / \\
\text { HP-C = high-protein isonitrogenous control diet, formulated with His-adequate protein sources to provide t } \\
\text { same MP supply as HP-FM. } \\
{ }^{2} \text { Church \& Dwight Co. Inc. (Ewing, NJ). }\end{array}$} \\
\hline \multicolumn{5}{|c|}{${ }^{4}$ Smartamine M (Adisseo Inc., Antony, France). } \\
\hline
\end{tabular}

ond or third parity $(111 \pm 4$ DIM and $650 \pm 14 \mathrm{~kg} \mathrm{BW})$ were assigned to 4 dietary treatments in a replicated 4 $\times 4$ Latin square design. A standard-protein control diet (SP-C) was formulated with soybean, corn gluten, and fish meal to provide $3,100 \mathrm{~g}$ of $\mathrm{MP} / \mathrm{d}$ according to NRC (2001; Table 1). Feather meal was added to the control diet either to replace the MP isonitrogenously $(\mathbf{S P}-\mathbf{F M})$ or to increase the MP supply to $3,484 \mathrm{~g} / \mathrm{d}$ (HP-FM) with a His-deficient protein source. As an isonitrogenous control for HP-FM, a high-protein diet (HP-C) was formulated with His-adequate protein sources to provide the same MP supply as HP-FM. The His content of MP was predicted by the NRC (2001) model to be $2.15,1.76,1.82$, and $2.32 \%$ on diets SP-C, SP-FM, HP-FM, and HP-C, respectively. Smartamine M (Adisseo Inc., Antony, France) was included in diets to bring the predicted Lys:Met ratio of MP to 3.1:1 on all treatments. The predicted Met content of MP was $1.96,1.69,1.68$, and $1.82 \%$ for SP-C, SP-FM, HP-FM, and $\mathrm{HP}-\mathrm{C}$, respectively.

Each period was 4 wk in duration. Cows were housed in tie-stalls and milked at 0600 and $1500 \mathrm{~h}$ daily. Milk was weighed at each milking and sampled during the last $5 \mathrm{~d}$ of each period for compositional analysis on a MilkoScan 4000 mid-infrared spectrometer (Foss Electric A/S, Hillerød, Denmark). Body weight was recorded at the end of the second and fourth periods. Cows were offered feed after each milking for ad libitum intake throughout the day. Refusals were removed and weighed before the morning feeding. During the last $5 \mathrm{~d}$ of each period, feed and orts were sampled daily for analysis of DM content by oven drying at $65^{\circ} \mathrm{C}$ for 
$24 \mathrm{~h}$. A pooled sample of the TMR from the last $5 \mathrm{~d}$ of each period was retained for compositional analysis at a commercial laboratory (Agri-Food Laboratories, Guelph, ON, Canada) by near-infrared spectroscopy (AOAC International, 1996). Blood was collected by tail venipuncture into EDTA and heparin Vacutainers (Becton Dickinson, Rutherford, NJ) on the last day of each period. Plasma was removed by centrifugation $\left(1,500 \times g\right.$, for $20 \mathrm{~min}$ at $\left.4^{\circ} \mathrm{C}\right)$ and frozen at $-20^{\circ} \mathrm{C}$ for subsequent analysis of glucose, acetate, triacylglycerol (TAG), NEFA, and urea by enzyme-linked spectrophotometry as previously described (Weekes et al., 2006). Plasma AA were quantified by reversed-phase ultraperformance liquid chromatography using the AccQTag derivatization method (Waters Chromatography Division, Milford, MA) as described by Boogers et al. (2008).

Energy balance was calculated as $\mathrm{NE}_{\text {intake }}-\mathrm{NE}_{\mathrm{L}}-$ $\mathrm{NE}_{\mathrm{M}}$, where $\mathrm{NE}_{\text {intake }}$ was calculated from observed DMI and its estimated net energy content, $\mathrm{NE}_{\mathrm{L}}$ was obtained from the regression equation of Tyrrell and Reid (1965) against observed milk fat, protein and lactose yields, and $\mathrm{NE}_{\mathrm{M}}=0.08 \mathrm{BW}^{0.75}$ (NRC, 2001).

Means of observations from each cow during the last week of each period were subjected to ANOVA using PROC MIXED of SAS (SAS Institute Inc., Cary, NC) according to the following model:

$$
\begin{gathered}
\mathrm{y}_{\mathrm{ijklm}}=\mu+\mathrm{sq}_{\mathrm{i}}+\operatorname{cow}_{\mathrm{j}(\mathrm{i})}+\mathrm{per}_{\mathrm{k}}+\mathrm{MP}_{1} \\
+\mathrm{FM}_{\mathrm{m}}+(\mathrm{MP} \times \mathrm{FM})_{\mathrm{lm}}+\varepsilon_{\mathrm{ijk} \mathrm{km}},
\end{gathered}
$$

where $\mathrm{y}_{\mathrm{ijklm}}$ is the dependent variable, $\mu=$ overall mean, $\mathrm{sq}_{\mathrm{i}}=$ fixed square effect $(\mathrm{i}=1$ to 2$), \operatorname{cow}_{\mathrm{j}(\mathrm{i})}=$ random cow within square effect ( $\mathrm{j}=1$ to 8$)$, per $_{\mathrm{k}}=$ fixed period effect $(\mathrm{k}=1$ to 4$), \mathrm{MP}_{1}=$ fixed $\mathrm{MP}$ effect $(\mathrm{l}=1$ to $2), \mathrm{FM}_{\mathrm{m}}=$ fixed feather meal effect $(\mathrm{m}=1$ to 2$)$, and $\varepsilon_{\mathrm{ijklm}}=$ experimental error. Least squares means were separated following a Tukey adjustment. Significance was declared at $P \leq 0.05$ and trends were declared at $0.05<P \leq 0.10$.

\section{RESULTS AND DISCUSSION}

The purpose of this study was to evaluate the ability of feather meal to induce milk composition changes typical of a His deficiency or imbalance. Infusion studies have shown that removal of His from abomasal AA infusates increases milk fat yield, whereas it decreases milk protein and lactose yields (Fraser et al., 1991; Kim et al., 1999; Bequette et al., 2000; Cant et al., 2001; Weekes et al., 2006). Isonitrogenous replacement of dietary MP with His-deficient feather meal (SP-FM) was intended to create a His deficiency compared with the control diet (SP-C), whereas adding feather meal to the diet (HP-FM) was done to create a His imbalance compared with SP-C.

\section{$B W$ and DMI}

Body weights measured after the second and fourth periods were not significantly different. Dry matter intake tended $(P=0.096)$ to decrease with feather meal inclusion (Table 2). This tendency for decreased DMI may be explained by the relatively large inclusion of feather meal which has poor palatability (Grant and Haddad, 1998). Compared with the $3.3 \mathrm{~kg} / \mathrm{d}$ added in this trial, adding just $1.25 \mathrm{~kg} / \mathrm{d}$ of feather meal to a grass silage-based diet significantly decreased feed intake and decreased milk yield by $3 \mathrm{~kg} / \mathrm{d}$ (Yeo et al., 2003). The large His deficiency induced by Weekes et al. (2006) by removal of His from an abomasal infusion dramatically decreased DMI by 35\% during the first $2 \mathrm{~d}$ of infusion but it recovered for the remainder of infusion. In nonruminants, decreased DMI during AA imbalance has been shown to be mediated by appetite centers of the brain (Gietzen, 1993). The feather meal diets may have been sufficiently His deficient to alter brain-mediated DMI.

Digestible essential AA (DEAA) flows were estimated for each treatment from average DMI values and ingredient composition of the diets using the NRC (2001) model (Table 2). Histidine, Met, and Lys flows were reduced on both feather meal diets compared with SP-C, whereas branched-chain AA, Phe, Arg, and Thr flows were similar between feather meal and SP-C. Total DEAA flows were equal between HP-FM and SP-C, but lower on SP-FM, suggesting that the HP-FM diet did not create an AA imbalance of excess AA over His as intended, but simply decreased His, Met, and Lys supplies. The imbalance was avoided, and deficiency created, by a decrease in DMI. Histidine, Leu, Phe, and Val flows were higher on the HP-C diet.

\section{Plasma AA Profile}

Feather meal inclusion at $12.6 \%$ of the diet either decreased (SP-FM) or maintained DEAA flow (HP-FM), yet plasma AA concentrations were affected similarly (Table 3). Histidine, Met, and Lys concentrations in plasma decreased, whereas Phe and the branched-chain AA increased. The reduction in His, Met, and Lys concentrations can be explained by the decrease in predicted digestible His, Met, and Lys supplies (Table 2). Increases in Phe and branched-chain AA, without an increase in digestible supply, suggests lower use in the body relative to SP-C, presumably due to deficiencies of His, Met, and Lys for protein synthesis. The deficien- 
Table 2. Least squares means of DMI $(\mathrm{kg} / \mathrm{d})$ and predicted flows of digestible AA $(\mathrm{g} / \mathrm{d})$ from NRC (2001) of 8 cows fed a standard- (SP) or high-protein (HP) diet with control ingredients (C) or feather meal (FM)

\begin{tabular}{lcccc}
\hline & \multicolumn{4}{c}{ Treatment } \\
\cline { 2 - 5 } Item & SP-C & SP-FM & HP-FM & HP-C \\
\hline $\mathrm{DMI}^{1}(\mathrm{~kg} / \mathrm{d})$ & 22.7 & 21.1 & 20.8 & 22.4 \\
$\mathrm{AA}(\mathrm{g} / \mathrm{d})$ & & & & \\
$\mathrm{Arg}$ & 133 & 122 & 133 & 134 \\
His & 61 & 48 & 54 & 73 \\
Ile & 134 & 130 & 138 & 324 \\
Leu & 253 & 242 & 265 & 176 \\
Lys & 174 & 143 & 49 & 57 \\
Met & 56 & 134 & 146 & 164 \\
Phe & 141 & 130 & 138 & 140 \\
Thr & 131 & 157 & 1,242 & 170 \\
Val & 150 & 1,151 & 1,377 \\
Totals & 1,233 & & & \\
\hline${ }^{1}$ Effect of MP level: $P_{\mathrm{MP}}=0.74$, feather meal inclusion: $P_{\mathrm{FM}}=0.096$, and their interaction: $P_{\mathrm{MP}} \times \mathrm{FM}$ & $=0.99$.
\end{tabular}

cies were severe enough to increase the sum of essential and total AA concentrations in plasma on both feather meal diets compared with SP-C. However, at 22, 21, and $41 \mu M$, respectively, the His, Met, and Lys deficiencies were not as severe as obtained in infusate deletion studies where plasma His was reduced to less than 13 $\mu M$ (Kim et al., 1999; Bequette et al., 2000; Weekes et al., 2006), and plasma Met and Lys were reduced to 7 and $33 \mu M$, respectively (Weekes et al., 2006). The similarity between SP-FM and HP-FM in total essential AA concentrations (Table 3), despite higher DEAA supply on the latter (Table 2), suggests that DEAA were utilized to a greater extent on the HP-FM diet.

Chamberlain et al. (1992) also found significantly $(0.01>P>0.001)$ lower plasma His, Met, Lys, and Trp, and higher Phe and Val concentrations with $0.8 \mathrm{~kg}$ of feather meal/d compared with $1.0 \mathrm{~kg}$ of fish meal $/ \mathrm{d}$. However, Yeo et al. (2003) reported no significant difference in plasma His, Phe or branched-chain AA $(P>$ $0.05)$ with $1.25 \mathrm{~kg} / \mathrm{d}$ of feather meal, compared with fish meal, although it did lower plasma Met, Lys, and $\operatorname{Arg}(0.05>P>0.001)$.

Several interactions between feather meal and MP level were significant because the HP-C increased plasma concentrations of many AA compared with SP-C, whereas feather meal inclusion produced very similar AA concentrations whether added to SP or HP diets.

\section{Plasma Metabolites}

Plasma glucose was not significantly affected by treatment (Table 4). Urea concentration was increased by higher MP $(P=0.044)$ but not by feather meal ( $P$ $=0.69$ ). As a proportion of DEAA supply (Table 2 ), plasma urea nitrogen (PUN) was higher for both the feather meal diets, which suggests that AA catabolism was increased. Elevated AA concentrations in plasma, due to the His, Met, and Lys deficiencies, may have stimulated catabolic pathways in the liver (Pestaña, 1969; Tovar et al., 2002). Both imbalances and deficiencies of essential AA increase PUN concentrations in cows (Weekes et al., 2006). Higher PUN concentration on the HP-FM diet compared with SP-FM is consistent with the assertion, based on similar essential AA concentrations in plasma, that DEAA were utilized to a greater extent on this diet.

When hepatic AA catabolism is stimulated in deficiency or imbalance states, it is not specific to only those AA in excess supply but the capacity for catabolism of the deficient AA is also upregulated (Keene and Austic, 2001), which exacerbates the deficiency state. Because this upregulation of catabolism, which is mediated by glucagon and total AA (Pestaña, 1969; Tovar et al., 2002), is not specific to individual AA, it appears that it is more important to avoid hyperaminoacidemia than it is to maintain protein accretion rates in tissues such as muscle and mammary glands (Cant et al., 2003). A similar decision, albeit via a different mechanism, may have been responsible for the DMI depression on HP-FM diets, where the oversupply of imbalanced DEAA was avoided, and a deficiency was created instead. Robinson et al. (2000) noted a similar decrease in DMI and, consequently, milk production, when rumen-protected Met and Lys were supplemented above the requirement, resulting in a deficiency rather than a potential imbalance.

Cows on the SP-C diet had significantly higher TAG concentrations in plasma compared with those on the other 3 diets. Plasma TAG concentrations typically reflect fat intakes but little difference was observed between diets in fat content. The TAG concentration 
Table 3. Least squares means of plasma AA concentrations $(\mu M)$ of 8 cows fed a standard- (SP) or high-protein (HP) diet with control ingredients $(\mathrm{C})$ or feather meal (FM)

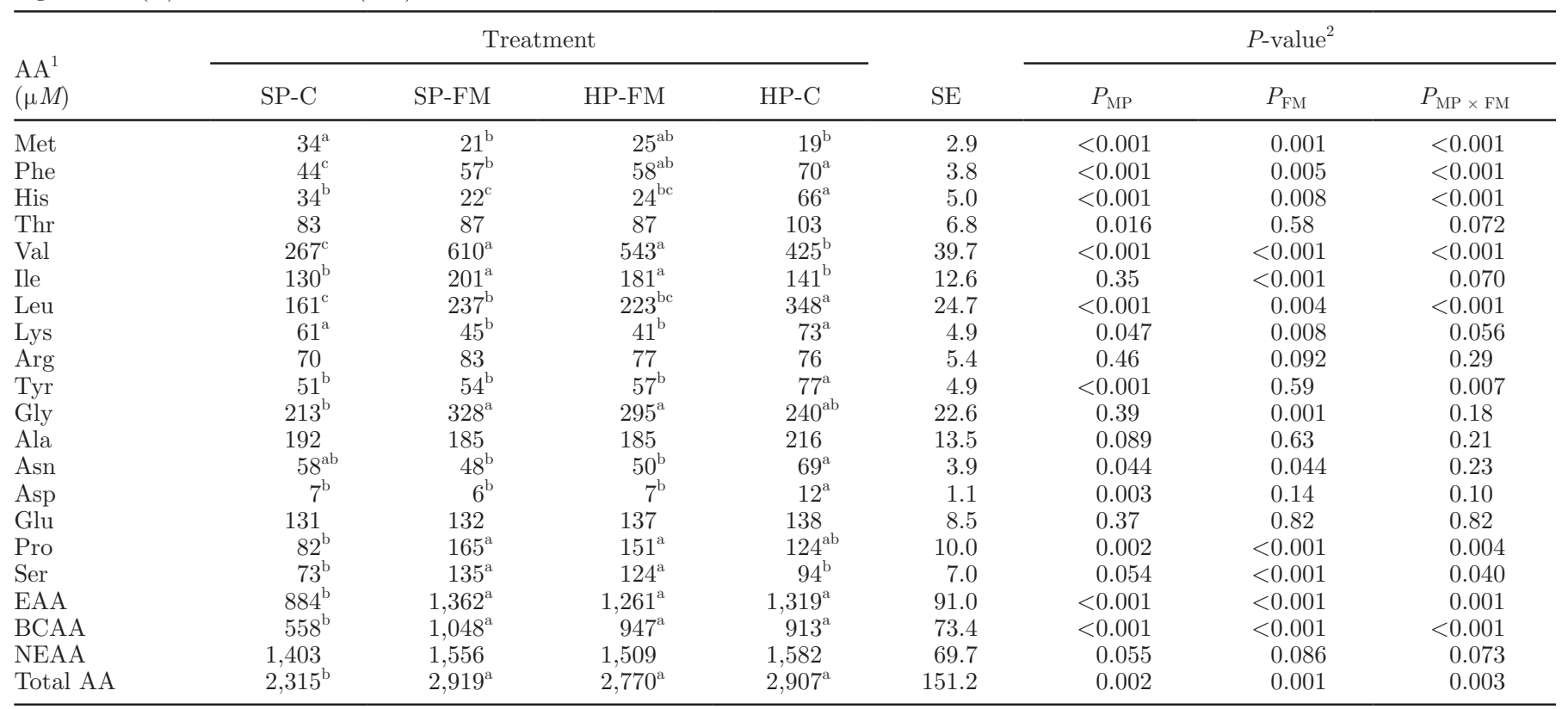

${ }^{\mathrm{a}-c}$ Means within a row with different superscripts are significantly different $(P<0.05)$.

${ }^{1} \mathrm{EAA}=$ essential $\mathrm{AA} ; \mathrm{BCAA}=$ branched-chain $\mathrm{AA} ; \mathrm{NEAA}=$ nonessential $\mathrm{AA}$.

${ }^{2}$ Effects of MP level $\left(P_{\mathrm{MP}}\right)$, feather meal inclusion $\left(P_{\mathrm{FM}}\right)$, and their interaction $\left(P_{\mathrm{MP}} \times \mathrm{FM}\right)$.

was elevated only $20 \%$ on the SP-C diet, so it appears to be of minor importance.

Plasma NEFA concentrations were elevated to 107 $\mu M$ on the HP-FM diet compared with $84 \mu M$ on all the others, creating a significant interaction of feather meal and MP $(P=0.013)$. Nonesterified FA are released from adipose tissue to maintain energy balance. Although net energy balance was not significantly affected (Table 4), mean DMI was lowest on the HPFM diet. The $23 \mu M$ increase in NEFA concentration is physiologically minor, given that NEFA levels are typically near $600 \mu M$ in early lactation when cows are truly in a negative energy balance and undergoing a massive metabolic shift to support lactation (Oikonomou et al., 2008).

\section{Milk Composition and Yield}

Feather meal inclusion at $12.6 \%$ of DM decreased milk production considerably compared with the control diets $(P<0.001)$, with cows on the SP-FM diet exhibiting the lowest production at $30.3 \mathrm{~kg} / \mathrm{d}$, compared with a high of $37.9 \mathrm{~kg} / \mathrm{d}$ on HP-C (Table 2). The lower milk production on the 2 feather meal diets is partly explained by the tendency for DMI to decrease. In contrast, lower levels of feather meal inclusion have produced different effects on DMI and milk yield than

Table 4. Least squares means of plasma metabolites of 8 cows fed a standard- (SP) or high-protein (HP) diet with control ingredients (C) or feather meal (FM)

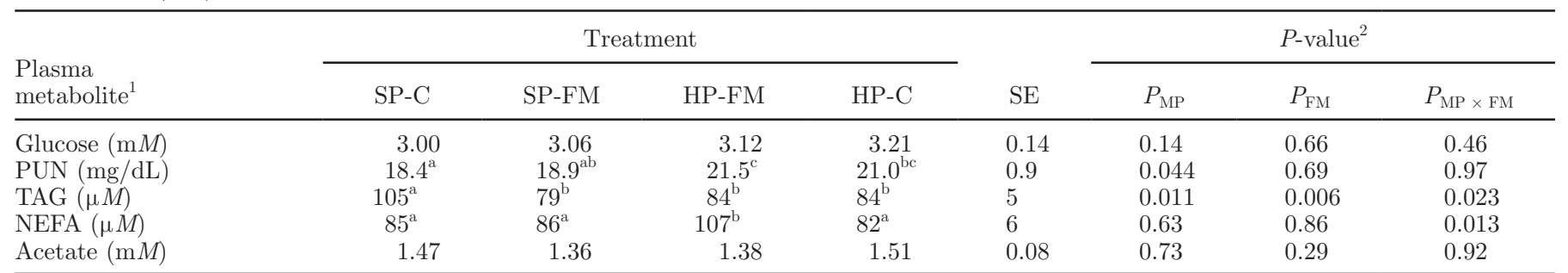

${ }^{\mathrm{a}-\mathrm{c}}$ Means within a row with different superscripts are significantly different $(P<0.05)$.

${ }^{1} \mathrm{PUN}=$ plasma urea nitrogen; TAG $=$ tricylglycerol.

${ }^{2}$ Effects of MP level $\left(P_{\mathrm{MP}}\right)$, feather meal inclusion $\left(P_{\mathrm{FM}}\right)$, and their interaction $\left(P_{\mathrm{MP} \times \mathrm{FM}}\right)$. 
Table 5. Least squares means of performance of 8 cows fed a standard- (SP) or high-protein (HP) diet with control ingredients (C) or feather meal (FM)

\begin{tabular}{|c|c|c|c|c|c|c|c|c|}
\hline \multirow[b]{2}{*}{ Item } & \multicolumn{4}{|c|}{ Treatment } & \multirow[b]{2}{*}{ SE } & \multicolumn{3}{|c|}{$P$-value ${ }^{1}$} \\
\hline & SP-C & SP-FM & HP-FM & $\mathrm{HP}-\mathrm{C}$ & & $P_{\mathrm{MP}}$ & $P_{\mathrm{FM}}$ & $P_{\mathrm{MP} \times \mathrm{FM}}$ \\
\hline \multicolumn{9}{|l|}{ Yield } \\
\hline Fat $(\mathrm{g} / \mathrm{d})$ & 1,356 & 1,231 & 1,267 & 1,287 & 88 & 0.36 & 0.11 & 0.33 \\
\hline Protein $(\mathrm{g} / \mathrm{d})$ & $1,191^{\mathrm{a}}$ & $860^{\mathrm{b}}$ & $998^{\mathrm{b}}$ & $1,213^{\mathrm{a}}$ & 41 & 0.68 & $<0.001$ & 0.14 \\
\hline Lactose (g/d) & $1,748^{\mathrm{a}}$ & $1,384^{\mathrm{b}}$ & $1,561^{\mathrm{ab}}$ & $1,739^{\mathrm{a}}$ & 71 & 0.92 & 0.001 & 0.16 \\
\hline Protein & $3.18^{\mathrm{a}}$ & $2.86^{\mathrm{c}}$ & $3.02^{\mathrm{b}}$ & $3.21^{\mathrm{a}}$ & 0.08 & 0.41 & $<0.001$ & 0.036 \\
\hline Lactose & 4.63 & 4.56 & 4.69 & 4.59 & 0.06 & 0.48 & 0.22 & 0.044 \\
\hline \multicolumn{9}{|l|}{ Ratio } \\
\hline Protein:fat & $0.92^{\mathrm{ab}}$ & $0.72^{\mathrm{c}}$ & $0.81^{\mathrm{bc}}$ & $1.00^{\mathrm{a}}$ & 0.05 & 0.11 & 0.001 & 0.88 \\
\hline SNF:fat & $2.56^{\mathrm{ab}}$ & $2.11^{\mathrm{bc}}$ & $2.33^{\mathrm{b}}$ & $2.73^{\mathrm{a}}$ & 0.16 & 0.18 & 0.002 & 0.79 \\
\hline NE balance $($ Mcal /d) & -0.4 & 0.9 & -0.8 & -0.8 & 1.3 & 0.66 & 0.14 & 0.28 \\
\hline
\end{tabular}

${ }^{\mathrm{a}-\mathrm{c}}$ Means within a row with different superscripts are significantly different $(P<0.05)$.

${ }^{1}$ Effects of MP level $\left(P_{\mathrm{MP}}\right)$, feather meal inclusion $\left(P_{\mathrm{FM}}\right)$, and their interaction $\left(P_{\mathrm{MP}} \times \mathrm{FM}\right)$.

observed here. Harris et al. (1992) included feather meal at 0,3 , or $6 \%$ of $\mathrm{DM}$ on diets of either $14 \% \mathrm{CP}$ or $18 \% \mathrm{CP}$ and found no effects on DMI at either protein percentage. In addition, feather meal at $3 \%$ inclusion on the $14 \% \mathrm{CP}$ diet actually increased milk yield by approximately $4 \mathrm{~kg} / \mathrm{d}$. The authors suggested that $3 \%$ feather meal increased undegraded protein intake from $30 \%$ of CP with no feather meal to a more optimal $34 \%$. Here, we appear to have decreased the DEAA supply on the SP-FM diet compared with SP-C and changed the profile of AA in an adequate DEAA supply on the HP-FM diet. In both cases, milk yield decreased, although to a greater extent on SP-FM.

Milk fat yield was not significantly affected by diet $(P>0.11)$ but protein $(P<0.001)$ and lactose yields $(P=0.001)$ were both reduced by feather meal. This resulted in a higher fat content $(P=0.014)$ of milk on feather meal diets and a lower protein percentage $(P<$ 0.001). Protein content was lowest on SP-FM at $2.86 \%$ and slightly higher on HP-FM at $3.02 \%$. Elevated MP supply had no effect on milk composition or yields of components $(P>0.10)$.

When inclusion of feather meal decreased DEAA supply, as seen in the SP-FM diet, milk protein yields decreased by $331 \mathrm{~g} / \mathrm{d}$. However, when DEAA supply was maintained in the HP-FM diet, milk protein yields decreased by only $193 \mathrm{~g} / \mathrm{d}$. The decreased milk protein yields are likely due to the low circulating concentrations of His, Met, and Lys. However, because essential AA concentrations in plasma were not different between SP-FM and HP-FM, it cannot be simply limiting AA concentrations that dictate milk protein yields. In fact, it may have been a stimulation of His, Met, and Lys partitioning into proteins, including those of milk, that caused plasma concentrations of these AA to decrease on HP-FM to the same levels observed on SPFM. Stimulation of the efficiency of plasma AA entry into proteins and catabolic pathways has been blamed for the reduction in plasma concentration of the missing essential AA during AA imbalance (Rogers, 1976; Keene and Austic, 2001). A similar situation may have arisen on the HP-FM diet, where higher DEAA supply than on SP-FM could have been responsible for the greater clearance.

Lactose yield was lowest on the SP-FM diet at 1,384 $\mathrm{g} / \mathrm{d}$, corresponding to the lowest milk yield. In comparison, HP-C produced the highest milk protein and lactose yields, corresponding to the highest milk yield.

When protein yields decreased on feather meal diets, no corresponding increase in fat yields was observed as had previously been observed during His deficiency and imbalance (Kim et al., 1999; Weekes et al., 2006). However, fat yields did not decline along with the protein and lactose yields, so there was an increase in milk fat content. An increased milk fat content is consistent with responses to His deficiencies and imbalances created by postruminal infusion (Fraser et al., 1991; Kim et al., 1999; Cant et al., 2001; Weekes et al., 2006). Yeo et al. (2003) also observed an increase in milk fat percentage without a change in milk fat yield when $1.25 \mathrm{~kg}$ of feather meal/d replaced an equivalent amount of fish meal in the diet. The fact that His did not reach as low a concentration in plasma on feather meal diets as in the infusion studies may account for the lack of stimulation of milk fat yield. Another possibility is that the tendency for lower DMI on feather meal diets countered a potential increase in milk fat yield. The underlying mechanism(s) that leads to an enhancement in milk fat content under His-limiting conditions is unknown. 
As a result of the reciprocal changes in milk protein and fat contents, the ratios of protein:fat and SNF:fat in milk decreased on both feather meal diets (Table 5). This change in ratios is particularly relevant to Canadian dairy farmers who are currently penalized if the SNF:fat ratio exceeds 2:25 to 2:30, depending on province. A common approach to lowering the SNF:fat ratio is to increase milk fat yield by increasing the forage content of the diet, but this often results in decreased milk yield (Moorby et al., 2006). Alternatively, altering the AA profile of MP could potentially be used to quickly and reliably lower SNF:fat to avoid penalties.

The SP-FM diet achieved the lowest SNF:fat ratio of 2.11 , compared with 2.56 on the SP-C diet. The HPFM diet reduced the SNF:fat ratio to 2.33 compared with the highest level at 2.73 on the HP-C diet. SP-FM was the only diet that lowered the SNF:fat ratio to below the penalty level, suggesting that adding feather meal to the diet by replacing MP isonitrogenously is more effective at lowering the SNF:fat ratio than increasing the MP content with an imbalanced protein source. Unfortunately, milk yield was also lowest on the SP-FM treatment. To our knowledge, $12.6 \%$ of DM, or $3.3 \mathrm{~kg} / \mathrm{d}$, is the highest level of feather meal inclusion studied to date. Future research should focus on determining the optimum feather meal inclusion level that reliably alters milk composition without compromising milk yield.

\section{ACKNOWLEDGMENTS}

The authors gratefully acknowledge the laboratory assistance of Richelle Curtis, Julie Kim, and Afshin Gholami at the University of Guelph (Guelph, ON, Canada). Financial support was provided by the Dairy Farmers of Canada (Ottawa, ON, Canada) and Natural Sciences and Engineering Research Council of Canada (NSERC, Ottawa, ON, Canada); P. Stahel was the recipient of an NSERC scholarship.

\section{REFERENCES}

AOAC International. 1996. Official Methods of Analysis. 16th ed. AOAC International, Arlington, VA.

Bequette, B. J., M. D. Hanigan, A. G. Calder, C. K. Reynolds, G. E. Lobley, and J. C. MacRae. 2000. Amino acid exchange by the mammary gland of lactating goats when histidine limits milk production. J. Dairy Sci. 83:765-775.

Boogers, I., W. Plugge, Y. Q. Stokkermans, and A. L. L. Duchateau. 2008. Ultra-performance liquid chromatographic analysis of amino acids in protein hydrolysates using an automated pre-column derivatisation method. J. Chromatogr. A 1189:406-409.

Cant, J. P., R. Berthiaume, H. Lapierre, P. H. Luimes, B. W. McBride, and D. Pacheco. 2003. Responses of the bovine mammary glands to absorptive supply of single amino acids. Can. J. Anim. Sci. 83:341-355.

Cant, J. P., D. R. Trout, F. Qiao, and B. W. McBride. 2001. Milk composition responses to unilateral arterial infusion of complete and histidine-lacking amino acid mixtures to the mammary glands of cows. J. Dairy Sci. 84:1192-1200.

Chamberlain, D. G., J.-J. Choung, and S. Robertson. 1992. Protein nutrition of dairy cows receiving grass silage diets: Effects of feeding protein supplement of unbalanced amino acid composition. J. Sci. Food Agric. 60:425-430.

Fraser, D. L., E. R. Ørskov, F. G. Whitelaw, and M. F. Franklin. 1991. Limiting amino acids in dairy cows given casein as the sole source of protein. Livest. Prod. Sci. 28:235-252.

Gietzen, D. W. 1993. Neural mechanisms in responses to amino acid deficiency. J. Nutr. 123:610-625.

Grant, R. J., and S. G. Haddad. 1998. Effect of a mixture of feather and blood meals on lactational performance of dairy cows. J. Dairy Sci. 81:1358-1363.

Harris, B., Jr., D. E. Dorminey, W. A. Smith, H. H. van Horn, and C. J. Wilcox. 1992. Effects of feather meal at two protein concentrations and yeast culture on production parameters in lactating dairy cows. J. Dairy Sci. 75:3524-3530.

Keene, J. C., and R. E. Austic. 2001. Dietary supplements of mixtures of indispensable amino acids lacking threonine, phenylalanine or histidine increase the activity of hepatic threonine dehydrogenase, phenylalanine hydroxylase or histidase, respectively, and prevent growth depressions in chicks caused by dietary excesses of threonine, phenylalanine, or histidine. J. Nutr. Biochem. 12:274-284.

Kim, C.-H., J.-J. Choung, and D. G. Chamberlain. 1999. Determination of the first-limiting amino acid for milk production in dairy cows consuming a diet of grass silage and a cereal-based supplement containing feather meal. J. Sci. Food Agric. 79:1703-1708.

Kim, C.-H., J.-J. Choung, and D. G. Chamberlain. 2000. Variability in the ranking of the three most-limiting amino acids for milk protein production in dairy cows consuming grass silage and a cereal-based supplement containing feather meal. J. Sci. Food Agric. 80:1386-1392.

Moorby, J. M., R. J. Dewhurst, R. T. Evan, and J. L. Danelón. 2006. Effects of dairy cow diet forage proportion on duodenal nutrient supply and urinary purine derivative excretion. J. Dairy Sci. 89:3552-3562

NRC. 2001. Nutrient Requirements of Dairy Cattle. 7th. Rev. ed. The National Academies Press, Washington, DC.

Oikonomou, G., G. E. Valergakis, G. Arsenos, N. Roubies, and G. Banos. 2008. Genetic profile of body energy and blood metabolic traits across lactation in primiparous Holstein cows. J. Dairy Sci. 91:2814-2822.

Pestaña, A. 1969. Dietary and hormonal control of enzymes of amino acid catabolism in liver. Eur. J. Biochem. 11:400-404.

Robinson, P. H., W. Chalupa, C. J. Sniffen, W. E. Julien, H. Sato, T. Fujieda, T. Ueda, and H. Suzuki. 2000. Influence of abomasal infusion of high levels of lysine or methionine, or both, on ruminal fermentation, eating behavior, and performance of lactating dairy cows. J. Anim. Sci. 78:1067-1077.

Rogers, Q. R. 1976. The nutritional and metabolic effects of amino acid imbalances. Pages 279-301 in Protein Metabolism and Nutrition. D. J. A. Cole, K. N. Boorman, P. J. Buttery, D. Lewis, R. J. Neale, and H. Swan, ed. Butterworths, London, UK.

Tovar, A. R., C. Ascencio, and N. Torres. 2002. Soy protein, casein, and zein regulate histidase gene expression by modulating serum glucagon. Am. J. Physiol. Endocrinol. Metab. 283:E1016-E1022.

Tyrrell, H. F., and J. T. Reid. 1965. Prediction of the energy value of cow's milk. J. Dairy Sci. 48:1215-1223.

Weekes, T. L., P. H. Luimes, and J. P. Cant. 2006. Responses to amino acid imbalances and deficiencies in lactating dairy cows. J. Dairy Sci. 89:2177-2187.

Yeo, J.-M., C. H. Knight, and D. G. Chamberlain. 2003. Effects of changes in dietary amino acid balance on milk yield and mammary function in dairy cows. J. Dairy Sci. 86:1436-1444. 